\title{
Synthesis of highly substituted 1,2-diazetidin-3-ones, small ring scaffolds for drug discovery
}

Marilia S. Santos, ${ }^{[a]}$ Andrew Nortcliffe, ${ }^{[a]}$ William Lewis, ${ }^{[a]}$ Tracey D. Bradshaw ${ }^{[b]}$ and Christopher J. Moody ${ }^{\star[a]}$

\section{Abstract}

1,2-Diazetidin-3-ones are readily accessible, small ring scaffolds that upon functionalization have the potential to produce diverse 3-dimensional structures for drug discovery. Thus treatment of diazo hydrazides, obtained from simple hydrazides and malonyl half ester derivatives, followed by diazo transfer, with catalytic amounts of rhodium(II) acetate dimer results in intramolecular carbenoid $\mathrm{N}-\mathrm{H}$ insertion to give 1,2-diazetidin-3-ones. Although subsequent functionalization reactions could be hampered by the lability of the 4-membered ring, a wide range of new derivatives was available by deprotection at $\mathrm{N}-1$, and subsequent amide or urea formation. The structures of four four-membered rings was confirmed by X-ray crystallography; the compounds showed modest growth inhibitory activity in mammary carcinoma cells.

\section{Introduction}

${ }^{*}{ }^{[a]}$ Ms M. S. Santos, Dr A. Nortcliffe, Dr W. Lewis, Prof Dr C. J. Moody, School of Chemistry, University of Nottingham, University Park, Nottingham NG7 2RD, U.K.

Email: c.j.moody@nottingham.ac.uk

${ }^{[b]} \operatorname{Dr}$ T. D. Bradshaw, School of Pharmacy, Centre for Biomolecular Science, University of Nottingham, University Park, Nottingham NG7 2RD, U.K.

Supporting information (experimental protocols, X-ray data and copies of NMR spectra) for this article is given via a link at the end of the document. 
Four-membered rings are increasingly prevalent as bioactive scaffolds in drug discovery programmes. ${ }^{[1]}$ Not only do they add structural novelty in under-explored areas of chemical space, they can also contribute to enhanced physicochemical properties. This has been amply illustrated by the dramatic increase in interest in oxetane ring systems in recent years. ${ }^{[2]}$ One four-membered ring that attracted our attention is the 1,2-diazetidin-3-one core structure (Figure 1). ${ }^{[3]}$ Although known for almost a 100 years, this small ring system remains largely unexplored in medicinal chemistry, but has recently attracted renewed attention following the discovery that they act as potent inhibitors of the serine hydrolase protein phosphatase methylesterase- 1 by acylation of the key serine residue. ${ }^{[4]}$ Notwithstanding their potential liability toward ring opening, these densely functionalized small rings possess welldefined vectors, and form a worthwhile low molecular weight scaffold for drug discovery.

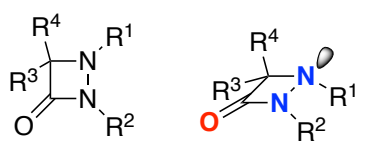

Figure 1. The 1,2-diazetidin-3-one scaffold.

To examine the potential molecular and structural diversity of the 1,2-diazetidin-3-one scaffold a virtual library was enumerated using LLAMA (Lead-Likeness And Molecular Analysis). ${ }^{[5]}$ A virtual library of 177 compounds based on 3 core scaffolds was shown to have suitable molecular properties as lead compounds for drug discovery $(\mathrm{RMM}=369, \mathrm{ALog} P=$ 1.11, pTSA $=104 \AA^{2}$ ). Additionally, the 1,2-diazetidinone fragment is highly distinctive from existing fragment databases. The Murko framework ${ }^{[6]}$ of the 1,2 -diazetidinone core was not found as a substructure in a random $2 \%$ sample of the ZINC database of commercially available compounds. ${ }^{[7]}$ Furthermore, examining the molecular shape of the virtual library using a PMI plot indicates that diverse three-dimensional molecular shape can be achieved by functionalization of the 1,2-diazetidinone core (Figure 2). 


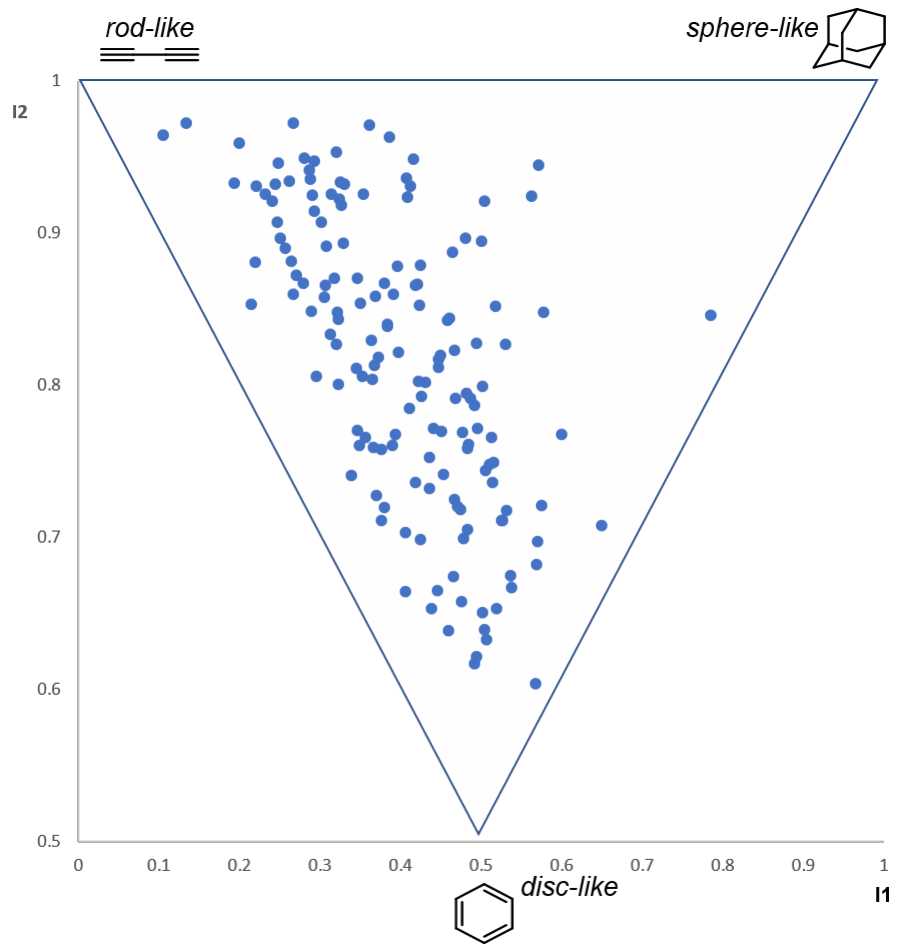

Figure 2. Principal moments of inertia (PMI) plot of the prepared scaffolds, generated using LLAMA.

In addition to being an attractive scaffold for further functionalization, 1.2-diazetidin-3-ones are aza-analogues of the well known $\beta$-lactam antibiotics. Despite being discovered 90 years ago, $\beta$-lactam antibiotics continue to play a key role in clinical practice and remain one of the best-investigated families of antibiotics. Their mode of action and susceptibility to resistance via $\beta$-lactamase enzymes have been widely studied, resulting in the chemical synthesis and biological evaluation of numerous derivatives and analogues. ${ }^{[8]}$ Much of the interest in analogues has focused on the modification of the ring system of naturally occurring $\beta$ lactams such as the penicillins and cephalosporins. Such analogues often incorporate an additional nitrogen atom in the ring, and include 2 -azapenems, ${ }^{[9]} 3$-azacephams, ${ }^{[9 b]}$ and 1azacephems (Figure 3). ${ }^{[10]}$ 1,2-Diazetidin-3-ones represent an alternative aza- $\beta$-lactam analogue that places the additional nitrogen in the four-membered ring itself. 
Naturally occurring $\beta$-lactams<smiles>[R7]NC1C(=O)N2[C@@H]1SC(C)(C)[C@H]2C(=O)O</smiles>

penams<smiles>[R]C1OC2CC(=O)N2C1C(=O)O</smiles>

clavams<smiles>[R]C1=C(C(=O)O)N2C(=O)C([R])C2C1</smiles>

carbapenems<smiles>[R7]CC1=C(C(=O)O)N2C(=O)C(N[R7])[C@H]2SC1</smiles>

$\mathrm{R}^{1} \mathrm{HN}$<smiles>[CH][C@@H]1CN(S(=O)(=O)O)C1=O</smiles>

cephems

monobactams

Synthetic aza- $\beta$-lactam analogues<smiles>O=C(O)[C@H]1N=CC2CC(=O)N21</smiles><smiles>O=C(O)[C@H]1NCCC2CC(=O)N21</smiles><smiles>[R]OC(=O)C1=C(C)CNC2C(N[Tl])C(=O)N12</smiles>

2-azapenem

1-azacephem

$$
\mathrm{O}_{\mathrm{N}^{2}}^{\mathrm{R}^{4}} \mathrm{~N}^{\mathrm{R}^{1}}
$$

1,2-diazetidin-3-ones

Figure 3. Naturally occurring $\beta$-lactams and some aza-analogues.

1,2-Diazetidin-3-ones were originally prepared almost a century ago by Staudinger by reaction of azo compounds with ketenes. ${ }^{[11]}$ The process has been subject of renewed interest with the development of enantioselective versions using asymmetric nucleophilic catalysis (Scheme 1A) ${ }^{[12]}$ although it remains somewhat limited in its substrate scope. In contrast, in seminal work Taylor and co-workers described versatile routes to 1,2-diazetidin3-ones based on the cyclization of benzophenone chloroacetylhydrazone, followed by treatment with 4-toluenesulfonic acid to give the parent ring system for further elaboration (Scheme 1B) ${ }^{[13]}$ Our own contributions centered on the intramolecular $\mathrm{N}-\mathrm{H}$ insertion reaction of rhodium carbene intermediates derived from diazocarbonyl compounds (Scheme 1C). ${ }^{[1]}$ 


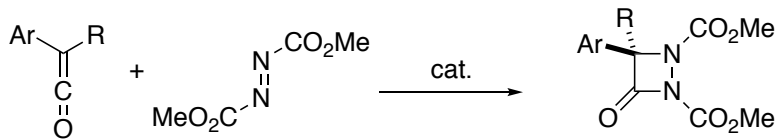

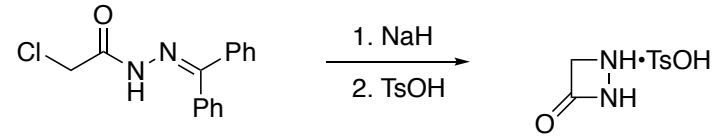

C

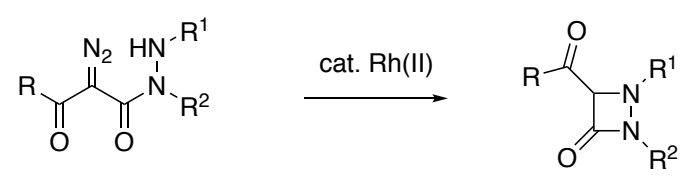

Scheme 1. Routes to 1,2-diazetidin-3-ones.

Despite the development of successful synthetic routes, ${ }^{[3]}$ 1,2-diazetidinones remain poorly investigated, and attempts to further develop their chemistry have often foundered due to their lability and inherent ring strain. We now report a detailed study on the synthesis of a range of 1,2-diazetidin-3-one scaffolds using the versatile rhodium carbene methodology, followed by their subsequent derivatization reactions, and preliminary biological evaluation.

\section{Results and Discussion}

The synthesis began with the reaction between benzaldehyde and tert-butyl carbazate followed by reduction with cyanoborohydride to form the hydrazine 1a. Treatment with methyl malonyl chloride and triethylamine in dichloromethane at room temperature gave the desired 1,3-dicarbonyl compound $\mathbf{2 a}$ in $70 \%$ yield (Scheme 2). Subsequent diazo group transfer reaction using $p$-acetamidobenzenesulfonyl azide $(p-A B S A)^{[15]}$ in the presence of DBU afforded diazocarbonyl compound $\mathbf{3 a}$ in good yield. The diazocarbonyl compound represents the key substrate for the overall strategy, and treatment with a catalytic amount of rhodium(II) acetate dimer (3 mol\%) induced metallocarbene formation and intramolecular $\mathrm{N}-\mathrm{H}$ insertion providing the 1,2-diazetidin-3-one $\mathbf{4 a}$ as a single product in $79 \%$ yield after chromatographic purification. The same synthetic sequence was applied to the hydrazine $\mathbf{1 b}$ derived from furfural, and delivered the 1,2-diazetidin-3-one $\mathbf{4 b}$ in comparable fashion. Likewise the 
corresponding benzyl ester 4c was prepared as outlined in Scheme 2. As expected, the 1,2diazetidin-3-ones exhibited a high frequency carbonyl stretch at ca. $1800 \mathrm{~cm}^{-1}$ in their IR spectra.

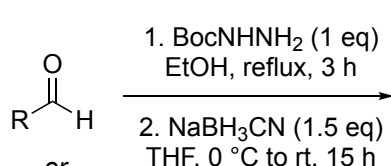

$$
\begin{aligned}
& \text { or } \\
& { }_{\mathrm{Me}}^{\stackrel{\mathrm{O}}{1}} \mathrm{Me}
\end{aligned}
$$

$$
\begin{aligned}
& \text { 1a } \mathrm{R}=\mathrm{Ph}, \mathrm{R}^{\prime}=\mathrm{H}(89 \%) \\
& \text { 1b } \mathrm{R}=2 \text {-furyl, } \mathrm{R}^{\prime}=\mathrm{H}(45 \%) \\
& \text { 1c } \mathrm{R}=\mathrm{R}^{\prime}=\mathrm{Me}(77 \%)
\end{aligned}
$$

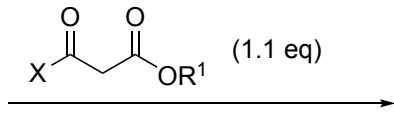

a, b, d, e; $\mathrm{X}=\mathrm{Cl}, \mathrm{R}^{1}=\mathrm{Me}$ or $\mathrm{Et}$; $\mathrm{Et}_{3} \mathrm{~N}, \mathrm{CH}_{2} \mathrm{Cl}_{2}, 0^{\circ} \mathrm{C}$ to rt, $15 \mathrm{~h}$ c; $\mathrm{X}=\mathrm{OH}, \mathrm{R}^{1}=\mathrm{Bn}$; HATU (2 eq) DIPEA, $\mathrm{CH}_{2} \mathrm{Cl}_{2}, 0^{\circ} \mathrm{C}$ to $\mathrm{rt}, 3 \mathrm{~h}$<smiles>[R20]C(=O)CC(=O)N(N)C([R])[R20]</smiles>

2a $\mathrm{R}=\mathrm{Ph}, \mathrm{R}$ ' $=\mathrm{H}, \mathrm{R}^{1}=\mathrm{Me}(70 \%)$ 2b R $=2$-furyl, $R^{\prime}=H, R^{1}=M e(68 \%)$ 2c $\mathrm{R}=\mathrm{Ph}, \mathrm{R}^{\prime}=\mathrm{H}, \mathrm{R}^{1}=\mathrm{Bn}(80 \%)$ 2d R = Ph, R' = H, R ${ }^{1}=$ Et (94\%) 2e $\mathrm{R}=\mathrm{R}^{\prime}=\mathrm{Me}, \mathrm{R}^{1}=\mathrm{Et}(91 \%)$<smiles>[R]CN1C(=O)C(C(=O)OC)N1C(C)=O</smiles><smiles>[R]CN1NC(C(=O)OC)C1=O</smiles>

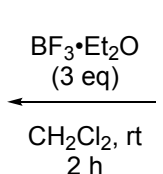<smiles>[R]CN1C(=O)C(C(=O)O[R20])C1C(=O)OCc1ccccc1</smiles><smiles></smiles>
p-ABSA (1.5 eq), DBU $\mathrm{MeCN}, 0{ }^{\circ} \mathrm{C}$ to $\mathrm{rt}, 3 \mathrm{~h}$<smiles>[R]CN(NC(=O)OC(C)(C)C)C(=O)C(=N)C(=O)O</smiles>

$$
\begin{aligned}
& \mathbf{5 a} \mathrm{R}=\mathrm{Ph}(85 \%) \\
& \mathbf{5 b} \mathrm{R}=2 \text {-furyl }(81 \%)
\end{aligned}
$$

3a $\mathrm{R}=\mathrm{Ph}, \mathrm{R}^{1}=\mathrm{Me}(70 \%)$

3b $\mathrm{R}=2$-furyl, $\mathrm{R}^{1}=\mathrm{Me}(92 \%)$ 3c $\mathrm{R}=\mathrm{Ph}, \mathrm{R}^{1}=\mathrm{Bn}(80 \%)$

Scheme 2. Synthesis of 1-Boc-1,2-diazetidinones, and their deprotection and re-acylation.

With the 4-membered heterocycle in hand, it was a priority to establish its ability to participate in a range of functionalization reactions. Initial attempts to remove the Boc-protecting group under standard acidic conditions were unsatisfactory, but exposure of aza- $\beta$-lactams $4 \mathbf{a}$ and $\mathbf{4 b}$ to boron trifluoride etherate ${ }^{[16]}$ resulted in clean removal of the nitrogen protecting group to deliver the 1,2-diazetidin-3-ones $\mathbf{5}$ in which $\mathrm{N}-1$ is free for further elaboration. Exemplar acylation reactions at $\mathrm{N}-1$ using acetyl chloride proceeded smoothly to provide derivatives 6 (Scheme 2).

In parallel, and in order to expand the structural variation in the 1,2-diazetidinones through functional group interconversion, we attempted to hydrolyze the 4-carboxylate ester in 1,2diazetidinone $\mathbf{4 a}$ to the corresponding carboxylic acid $\mathbf{7}$. Standard alkaline hydrolysis 
conditions resulted in rapid consumption of ester $\mathbf{4 a}$, but no carboxylic acid $\mathbf{7}$ could be isolated. Likewise use of $\mathrm{Me}_{3} \mathrm{SiOK}$ or $\mathrm{Me}_{3} \mathrm{SnOH}$ as reagents was unsuccessful. In all cases, a complex mixture of products was observed, suggesting that the 1,2-diazetidin-3-one ring is unstable under such conditions. Therefore, we switched our attention to the corresponding benzyl ester $\mathbf{4 c}$ in the expectation that it could be cleaved under non-nucleophilic conditions by hydrogenolysis. In the event, this was the case, and the carboxylic acid 7 could be isolated in $65 \%$ yield after hydrogenolysis over palladium on charcoal (Scheme 3 ). However, the acid 7 proved to be unstable, and decomposed within a few hours of its preparation. ${ }^{1} \mathrm{H}$ and ${ }^{13} \mathrm{C}$ NMR spectroscopic analysis of the resulting degradation products did not provide evidence for decomposition by a simple process such as decarboxylation. Nevertheless a range of amide coupling reactions was investigated using benzylamine as a model amine nucleophile. The first amide coupling agent evaluated was HATU which enabled the formation of amide $\mathbf{8}$, the structure of which was confirmed by X-ray crystallography, in poor yield of $21 \%$. Use of $E D C I, C D I$ or $P y B O P \circledast$ was unsuccessful, whereas other coupling agents such as 4-(4,6-dimethoxy-1,3,5-triazin-2-yl)-4-methyl-morpholinium chloride (DMTMM), prepared in situ from 2-chloro-4,6-dimethoxy-1,3,5-triazine (CDMT) and $N$ methylmorpholine (NMM), and propylphosphonic anhydride (T3P) resulted in similar yields for amide 8. Direct amidation attempts using the trimethylaluminum reagent, DABAL-Me ${ }_{3}{ }^{[17]}$ also gave disappointing results. Presumably the low yields in amide coupling reactions again reflect the instability of 1,2-diazetidinone-4-carboxylic acid. 


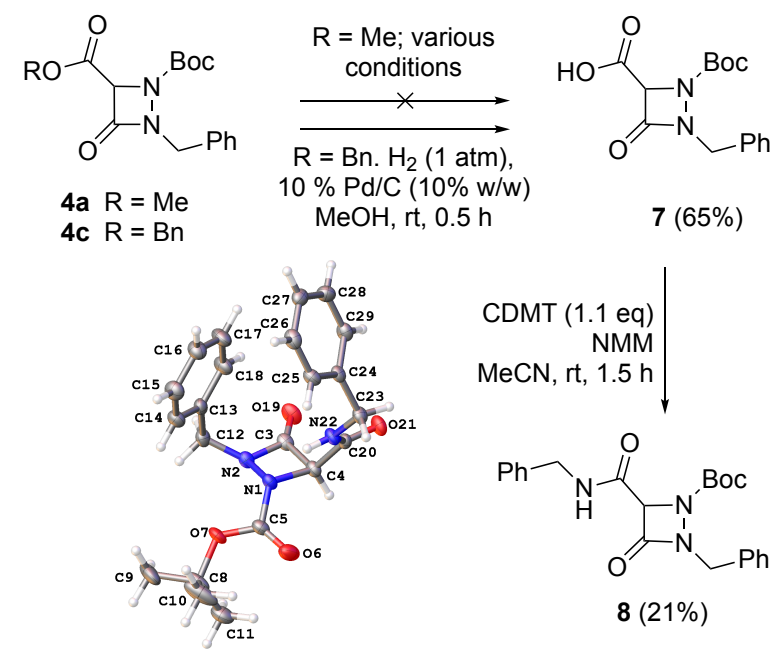

Scheme 3. Formation of 1,2-diazetidinone-4-carboxylic acid, and amide formation; X-ray crystal structure of amide 8 (CCDC 1829702).

Given the instability of the 1,2-diazetidinone-4-carboxylic acid, and the resulting poor yields in amide formation, we investigated the alternative strategy in which the amide is formed before the construction of the 4-membered ring. Thus hydrazine derivatives $\mathbf{2 b}, \mathbf{2} \mathbf{d}$ and $\mathbf{2 e}$ (Scheme 2) were hydrolyzed to the corresponding acids in near quantitative yields, and coupled to morpholine as a representative amine to give the amides 9 (Scheme 4). Diazo transfer proceeded smoothly using o-nitrobenzenesulfonyl azide (o-NBSA) ${ }^{[18]}$ the original conditions employing $p$-ABSA being unsatisfactory. The resulting diazocarbonyl compounds $\mathbf{1 0}$ underwent rhodium(II) catalyzed $\mathrm{N}-\mathrm{H}$ insertion to give the 1,2-diazetidin-3-ones 11. As before, treatment with boron trifluoride etherate successfully removed the $\mathrm{N}-1$ protecting group in good to excellent yield, and the resulting amine 12 underwent amide coupling with a range of representative acid chlorides to give amides 13a-f (Scheme 4). The structures of amides $\mathbf{1 3 a}, \mathbf{1 3 b}$ and $\mathbf{1 3 d}$ were confirmed by X-ray crystallography (Figure 4). In a similar manner, 1,2-diazetidinone 12a reacted with isocyanates to give a range of ureas 14 (Scheme $5)$. 


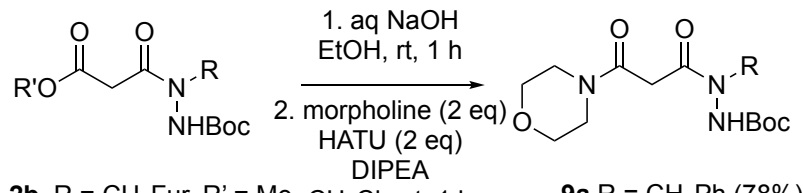

2b $\mathrm{R}=\mathrm{CH}_{2}$ Fur, R' $=\mathrm{Me} \mathrm{CH}_{2} \mathrm{Cl}_{2}$, it, $1 \mathrm{~h}$ 9a $\mathrm{R}=\mathrm{CH}_{2} \mathrm{Ph}(78 \%)$

2d $\mathrm{R}=\mathrm{CH}_{2} \mathrm{Ph}, \mathrm{R}^{\prime}=\mathrm{Et}$ 2e $\mathrm{R}=i-\operatorname{Pr}, \mathrm{R}^{\prime}=\mathrm{Et}$

9c $\mathrm{R}=i$ - $\operatorname{Pr}(82 \%)$

$$
\begin{aligned}
& \mid \begin{array}{l}
\text { o-NBSA (1.5 eq) } \\
\text { DBU } \\
\mathrm{MeCN} \\
0^{\circ} \mathrm{C} \text { to rt, } 1 \mathrm{~h}
\end{array} \\
& \overbrace{O^{\prime}}^{N^{\prime}}
\end{aligned}
$$

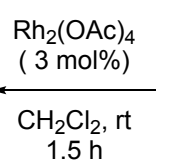

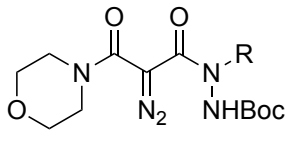

$$
\begin{aligned}
& \text { 11a } \mathrm{R}=\mathrm{CH}_{2} \mathrm{Ph}(63 \%) \\
& \text { 11b } \mathrm{R}=\mathrm{CH}_{2} \mathrm{Fur}(77 \%) \\
& \text { 11c } \mathrm{R}=i-\operatorname{Pr}(56 \%) \\
& \text { 10a } \mathrm{R}=\mathrm{CH}_{2} \mathrm{Ph}(54 \%) \\
& \text { 10b } \mathrm{R}=\mathrm{CH}_{2} \mathrm{Fur}(37 \%) \\
& 10 \mathrm{c} R=i-\operatorname{Pr}(55 \%) \\
& \mid \begin{array}{l}
\mathrm{BF}_{3} \cdot \mathrm{Et}_{2} \mathrm{O}(3 \mathrm{eq}) \\
\mathrm{CH}_{2} \mathrm{Cl}_{2}, 0^{\circ} \mathrm{C} \text { to rt } \\
1.5 \mathrm{~h}
\end{array} \\
& \text { 13a } \mathrm{R}=\mathrm{CH}_{2} \mathrm{Ph}, \mathrm{R}^{1}=\mathrm{Me}(97 \%) \\
& \text { 13b } \mathrm{R}=\mathrm{CH}_{2} \mathrm{Ph}, \mathrm{R}^{1}=\mathrm{Ph}(56 \%) \\
& \text { 13c } \mathrm{R}=\mathrm{CH}_{2} \mathrm{Ph}, \mathrm{R}^{1}=4-\mathrm{MeO}-\mathrm{C}_{6} \mathrm{H}_{4}(78 \%) \\
& \text { 13d } \mathrm{R}=\mathrm{CH}_{2} \mathrm{Ph}, \mathrm{R}^{1}=4-\mathrm{Br}-\mathrm{C}_{6} \mathrm{H}_{4}(27 \%) \\
& \text { 13e } \mathrm{R}=\mathrm{CH}_{2} \mathrm{Ph}, \mathrm{R}^{1}=2 \text {-thienyl }(73 \%) \\
& 13 f \mathrm{R}=i-\mathrm{Pr}, \mathrm{R}=\mathrm{Me}(62 \%)
\end{aligned}
$$

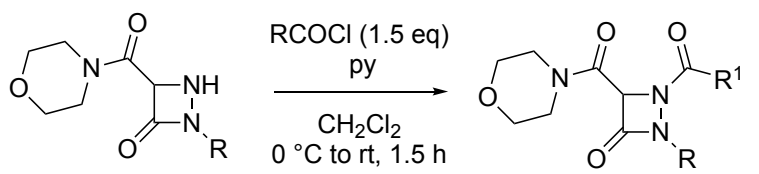

Scheme 4. [Fur $=2$-furyl] Synthesis of 1,2-diazetidinone-4-carboxamides.

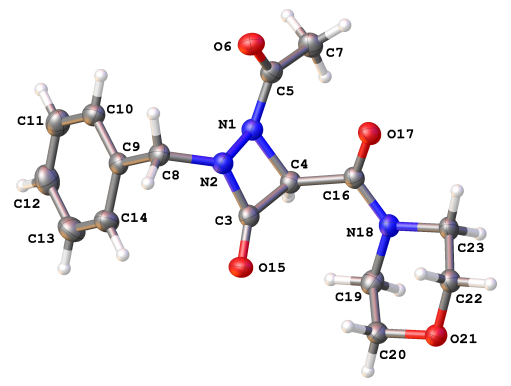

$13 a$

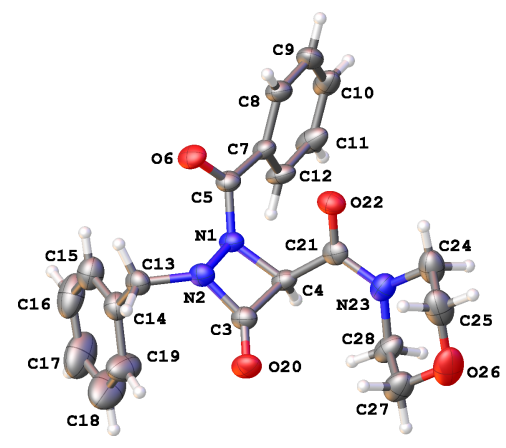

$13 b$

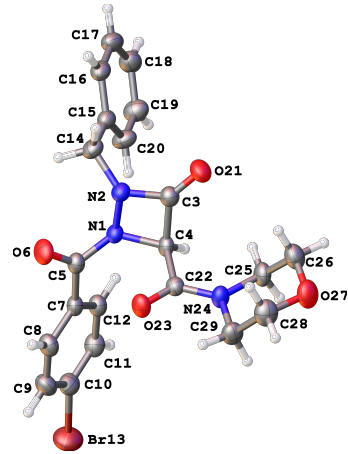

13d

Figure 4. X-Ray crystal structures of 1,2-diazetidin-3-ones 13a, 13b and 13d (CCDC 1829700, 1829701, 1829703 respectively). 


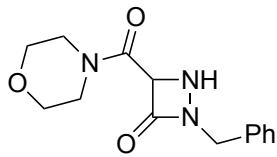

$12 a$

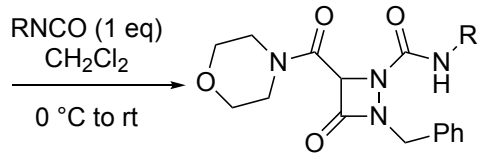

14a $\mathrm{R}=c-\mathrm{C}_{5} \mathrm{H}_{9}(72 \%)$

14b $\mathrm{R}=\mathrm{C}_{5} \mathrm{H}_{11}(69 \%)$

14c $\mathrm{R}=4-\mathrm{NO}_{2}-\mathrm{C}_{6} \mathrm{H}_{4}(70 \%)$

14d $\mathrm{R}=t-\mathrm{Bu}(32 \%)$

Scheme 5. Synthesis of 1,2-diazetidin-3-one ureas.

With a range of novel 1,2-diazetidin-3-ones in hand, it remained to carry out preliminary biological evaluation. The compounds were tested against a range of bacterial and fungal strains as part of the CO-ADD (Australia) antimicrobial screen, but for the most part were inactive. Compounds $13 \mathrm{e}$ and $14 \mathrm{~b}$ showed activity antifungal activity against Cryptococcus neoformans var. grubii showing $91 \%$ and $51 \%$ inhibition of growth respectively after $2 \mathrm{~h}$ incubation. Further structure-activity relationship studies are ongoing.

The compounds were also screened against two cancer cell lines: MCF-7 (mammary carcinoma) and HCT116 (colon carcinoma), using the MTT assay. The results are summarized in Table 1, and show that the compounds were largely inactive against colon carcinoma cells, but showed modest growth inhibitory activity in mammary carcinoma cells.

Table 1. Growth inhibitory activity of 1,2-diazetidin-3-ones in MCF-7 and HCT-116 carcinoma cells lines.

\begin{tabular}{ccc}
\hline \multirow{2}{*}{ Compound } & \multicolumn{2}{c}{ Gl $\mathbf{l}_{50}$ mean \pm SEM $(\mu \mathrm{M})$} \\
\cline { 2 - 3 } & MCF-7 & HCT-116 \\
\hline 5a & $72.7 \pm 12.3$ & $>100$ \\
5b & $76.0 \pm 7.51$ & $>100$ \\
$6 \mathbf{a}$ & $82.0 \pm 18.0$ & $>100$ \\
\hline
\end{tabular}




\begin{tabular}{ccc}
\hline $\mathbf{6 b}$ & $95.3 \pm 6.69$ & $>100$ \\
$\mathbf{1 2 b}$ & $54.3 \pm 4.18$ & $>100$ \\
$13 a$ & $64.0 \pm 3.51$ & $>100$ \\
$13 b$ & $67.3 \pm 6.06$ & $>100$ \\
$13 c$ & $26.3 \pm 21.9$ & $41.3 \pm 23.9$ \\
$13 d$ & $49.3 \pm 10.7$ & $>100$ \\
$13 e$ & $52.3 \pm 2.60$ & $>100$ \\
$13 f$ & $66.3 \pm 12.9$ & $>100$ \\
$14 c$ & $57.3 \pm 9.70$ & $>100$
\end{tabular}

MCF-7 breast cancer cells; HCT-116 colon cancer cells; cells were exposed to experimental agents for $48 \mathrm{~h}$ before viability was assessed by MTT assay. Mean \pm SEM (standard error of the mean) of $\geq 3$ independent trials are shown; $n=4$ per concentration per trial.

\section{Conclusion}

A range of 1,2-diazetidine-3-ones has been synthesized using intramolecular $\mathrm{N}-\mathrm{H}$ insertion of a rhodium carbenoid as a key step. Although some attempts at subsequent derivatization could be thwarted by the lability of the 4-membered ring, a range of derivatives was accessed by functionalization of the pendant carboxylate group prior to cyclization. The compounds show modest biological activity. 


\section{Experimental Section}

Full experimental details are given in the Supporting Information, together with copies of NMR spectra.

\section{Acknowledgements}

We thank CAPES (10719/2014-08) for financial support (to M.S.S.). A.N.'s contribution was carried out within the European Lead Factory and has received support from the Innovative Medicines Initiative Joint Undertaking under grant agreement no. 115489, resources of which are composed of financial contribution from the European Union's Seventh Framework Programme (FP7/2007-2013) and EFPIA companies' in-kind contribution. Antimicrobial screening was performed by CO-ADD (The Community for Antimicrobial Drug Discovery), funded by the Wellcome Trust (UK) and The University of Queensland (Australia).

\section{Conflict of interest}

The authors declare no conflicts of interest.

Keywords: 4 -membered rings $\cdot$ carbene insertion $\cdot$ heterocycles $\cdot$ drug discovery $\cdot$ leadoriented synthesis

\section{References}

[1] (a) E. M. Carreira, T. C. Fessard, Chem. Rev. 2014, 114, 8257-8322; (b) M. RogersEvans, H. Knust, J. M. Plancher, E. M. Carreira, G. Wuitschik, J. Burkhard, D. B. Li, C. Guerot, Chimia 2014, 68, 492-499.

[2] (a) J. A. Burkhard, G. Wuitschik, M. Rogers-Evans, K. Mueller, E. M. Carreira, Angew. Chem. Int. Ed. 2010, 49, 9052-9067; (b) J. A. Bull, R. A. Croft, O. A. Davis, R. Doran, K. F. Morgan, Chem. Rev. 2016, 116, 12150-12233; (c) S. M. Nicolle, A. 
Nortcliffe, H. E. Bartrum, W. Lewis, C. J. Hayes, C. J. Moody, Chem. Eur. J. 2017, 23, 13623-13627; (d) G. C. Geary, A. Nortcliffe, C. A. Pearce, D. Hamza, G. Jones, C. J. Moody, Bioorg. Med. Chem. 2018, 26, 791-797.

[3] L. N. Jungheim, in Adv. Heterocycl. Chem., Vol. 110 (Ed.: A. R. Katritzky), 2013, pp. 145-174.

[4] (a) D. A. Bachovchin, J. T. Mohr, A. E. Speers, C. Wang, J. M. Berlin, T. P. Spicer, V. Fernandez-Vega, P. Chase, P. S. Hodder, S. C. Schurer, D. K. Nomura, H. Rosen, G. C. Fu, B. F. Cravatt, Proc. Nat. Acad. Sci. USA 2011, 108, 6811-6816; (b) A. M. Zuhl, J. T. Mohr, D. A. Bachovchin, S. Niessen, K. L. Hsu, J. M. Berlin, M. Dochnahl, M. P. Lopez-Alberca, G. C. Fu, B. F. Cravatt, J. Am. Chem. Soc. 2012, 134, 5068-5071.

[5] I. Colomer, C. J. Empson, P. Craven, Z. Owen, R. G. Doveston, I. Churcher, S. P. Marsden, A. Nelson, Chem. Commun 2016, 52, 7209-7212.

[6] G. W. Bemis, M. A. Murcko, J. Med. Chem. 1996, 39, 2887-2893.

[7] J. J. Irwin, T. Sterling, M. M. Mysinger, E. S. Bolstad, R. G. Coleman, J. Chem. Inf. Model. 2012, 52, 1757-1768.

[8] P. Rutledge, P. Devi, ChemBioChem 2017, 18, 339-351.

[9] (a) W. F. Huffman, K. G. Holden, T. F. Buckley, J. G. Gleason, L. Wu, J. Am. Chem. Soc. 1977, 99, 2352-2353; (b) C. L. Branch, M. J. Pearson, Chem. Commun. 1981, 946-947.

[10] S. Wolfe, W. S. Lee, G. Kannengiesser, J. B. Ducep, Can. J. Chem. 1972, 50, 2902-2905.

[11] H. Staudinger, Helv. Chim. Acta 1922, 5, 103-108.

[12] (a) J. M. Berlin, G. C. Fu, Angew. Chem. Int. Ed. 2008, 47, 7048-7050; (b) X. L. Huang, X. Y. Chen, S. Ye, J. Org. Chem. 2009, 74, 7585-7587.

[13] (a) E. C. Taylor, R. J. Clemens, H. M. L. Davies, N. F. Haley, J. Am. Chem. Soc. 1981, 103, 7659-7660; (b) E. C. Taylor, H. M. L. Davies, R. J. Clemens, H. Yanagisawa, N. F. Haley, J. Am. Chem. Soc. 1981, 103, 7660-7661; (c) E. C. Taylor, 
R. J. Clemens, H. M. L. Davies, J. Org. Chem. 1983, 48, 4567-4571; (d) E. C. Taylor, H. M. L. Davies, W. T. Lavell, N. D. Jones, J. Org. Chem. 1984, 49, 2204-2208; (e) E. C. Taylor, H. M. L. Davies, J. S. Hinkle, J. Org. Chem. 1986, 51, 1530-1536; (f) E. C. Taylor, H. M. L. Davies, J. Org. Chem. 1986, 51, 1537-1540.

[14] G. Lawton, C. J. Moody, C. J. Pearson, J. Chem. Soc., Perkin Trans. 11987, 899902.

[15] J. S. Baum, D. A. Shook, H. M. L. Davies, H. D. Smith, Synth. Commun. 1987, 17, 1709-1716.

[16] E. F. Evans, N. J. Lewis, I. Kapfer, G. Macdonald, R. J. K. Taylor, Synth. Commun. 1997, 27, 1819-1825.

[17] A. Novak, L. D. Humphreys, M. D. Walker, S. Woodward, Tetrahedron Lett. 2006, 47, 5767-5769.

[18] B. H. Brodsky, J. Du Bois, Org. Lett. 2004, 6, 2619-2621. 